\title{
A Note on the Vegetative Anatomy of Pherosphaera Fitzgeraldi, F. v. M.
}

BY

\author{
PERCY GROOM, M.A., D.Sc., \\ Professor of the Technology of Woods and Fillres, Imperial College, London.
}

With one Figure in the Text.

PHEROSPHAERA is a coniferous genus separated by Archer from Dacrydium, but by some botanists placed within this genus. It includes only two species, both Australian-P. hookeriana, Archer, restricted to alpine Tasmania, and P. Fitzgeraldi, F. v. M., only known to occur on the Blue Mountains of New South Wales.

The latter species is a dense, prostrate little shrub, whose slender twigs are clothed with numerous narrow, keeled, leaves, which are about $3 \mathrm{~mm}$. in length. In their book 'The Pines of Australia', Baker and Smith state that the plant is 'found at the base of most of the chief falls', and add that their material (used in the present investigation) was obtained at the Lower Falls, Leura, in which site the shrub 'only grows where it can catch the drips from the falls'.

The remarkable nature of the habitat, recalling that of certain Hymenophyllaceae in tropical forests, caused me to examine the structure of the wood and leaves, in the hope of discovering a conifer truly hygrophytic in structure.

\section{a. THE WoOD.}

In its construction the wood of the stem by no means suggests a hygrophyte. In the thickest stem available the diameter was $4.5 \mathrm{~mm}$., yet the number of annual rings present was thirteen. The radial thickness of each annual ring was therefore $0.173 \mathrm{~mm}$., and thus represented 144 annual rings to the inch radius. The thickness of the annual rings increased outwards from the first to the tenth, but decreased in the remaining three rings; it is therefore probable that the stem had passed its maximum rate of growth in radial thickness.

All the tracheides of the secondary wood are thick-walled, and recall those forming the summer-wood (autumn-wood) of such a conifer as Pinus

[Annals of Botany, Vo1. XXX. No. CXVIII. April, 1916.] 
sylvestris, especially as their lumina are narrow. But the inmost tracheides, often exactly one series, of the annual ring show wider cavities than elsewhere, and thus represent a microscopically thin 'pore-zone' of springwood.

The bordered pits of the tracheides are mainly on the radial walls, where they are by no means abundant, being uniseriate even in the spring-wood; their fusiform apertures are spirally directed, and in the summer-wood exceed in length the diameter of the chamber. Bordered pits also occur on the tangential walls, more especially of tracheides forming the outer boundary of the annual ring.

The medullary rays are all uniseriate and remarkable for their shallowness, being usually only i to 4 , occasionally 5 , cells in height. They consist solely of thin-walled parenchyma, in the lateral radial walls of which the pits are nearly equal to the height of the cell, or each pit of such a kind is replaced by two superposed ones.

\section{THE LEAF.}

The leaf is xerophytic in structure. In the first place the epidermis has a thick cuticle and otherwise thick walls, while the stomata are sunken. Secondly, there is a single layer of thick-walled hypoderma, which is continuous except within the stomatic apertures.

Contrasting with this tegumentary system is the very loose green tissue lying within and simulating palisade-parenchyma though excavated by a large intercellular system.

The centre of the leaf is occupied by a strand that is denser in structure, except that it includes a large median ventral resin-duct. The feature worthy of special note is the extensive development of the transfusion-tissue in comparison with the puny xylem proper.

The stomata are restricted to the upper face of the leaf, where they are ranged in several longitudinal rows. In each row the successive stomata are mostly separated merely by a single short epidermal cell, but nearer the ends of such a row these single short cells become replaced by longer ones, or by only two or several cells. The longitudinal rows of stomata are separated laterally from one another by only two lines of epidermal cells.

The communication of the stoma with the internal atmosphere of the leaf is sharply limited. For within each stoma the gap not only in the thick-walled hypoderma, but also in the mesophyll lying within, is very small ; indeed the interruption in the latter tissue is limited to the local separation of either two or three cells, which, in surface section, bound an intercellular space whose oval outline approximately coincides with the periphery of the guard-cells.

The hypoderma at certain isolated spots, in transverse section, is as much as three cells in thickness. 
The green tissue immediately within the hypoderma deviates from typical palisade-parenchyma as regards both shape and orientation of the cells and dimensions of the intercellular spaces. The general design of this loose tissue is that of two layers of elongated cells, simulating palisade-cells, and stretching between the hypoderma and the central strand of the leaf. These cells, and particularly those forming the outer layer, are mainly perpendicular to the leaf-surface, but those radiating from the central strand towards the lateral angles (in transverse section) deviate from this design so greatly that in the angles they are actually tangential to the local curved surface. The cells forming the outer green layer frequently are lobed either

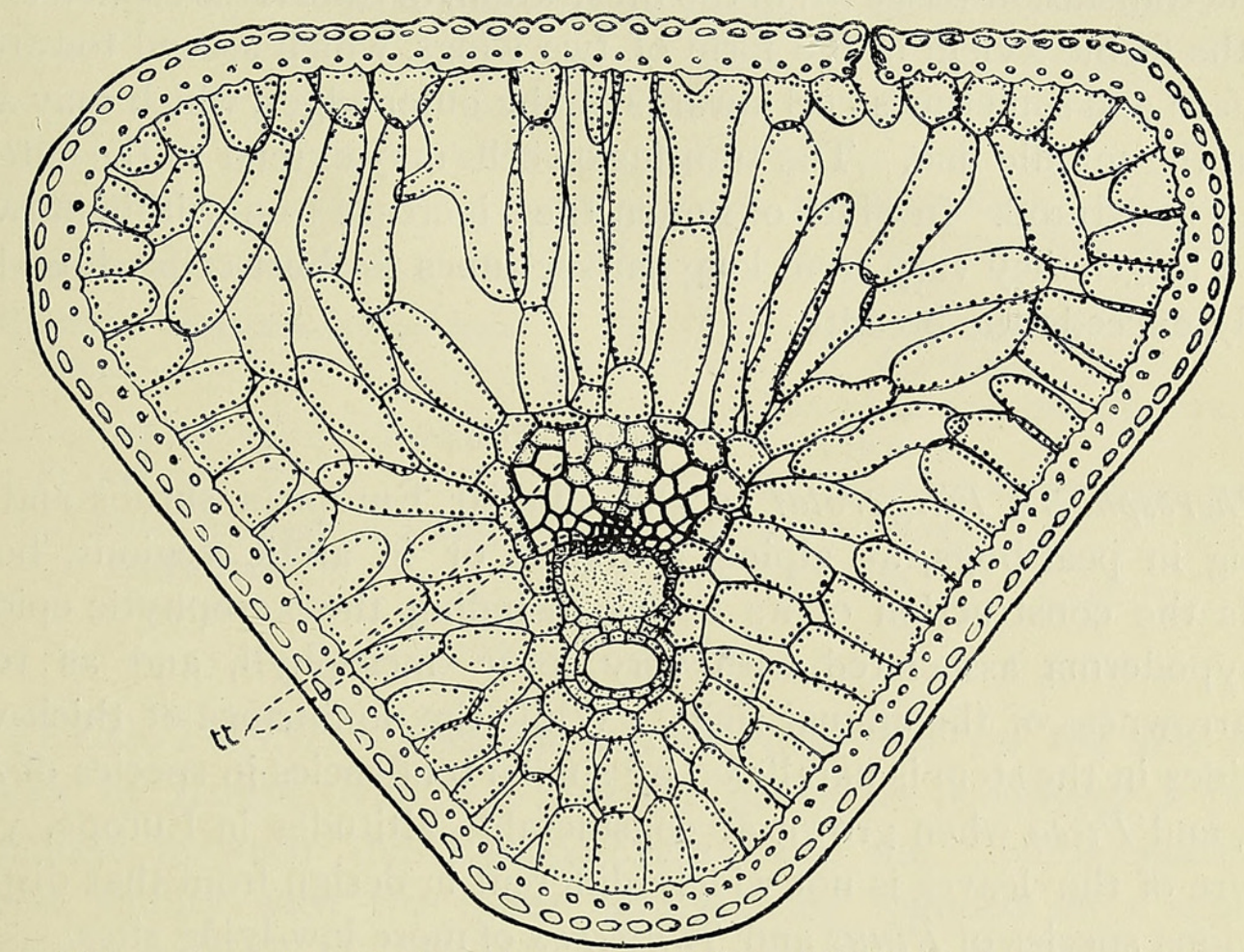

Transverse section of leaf of Pherosphaera Fitzgeraldi (slightly diagrammatic).

laterally or basally, or have dilated bases ; this is especially the case within the upper face of the leaf, so that here in transverse section a number of structures may be seen that apparently are short cells but really are the basal portions of long cells. The green cells of the outer series attain their maximum length towards the upper face of the leaf.

The cells forming the inner layer of palisade-like tissue on reaching the central strand may bend so that their inner portions run parallel to the length of the leaf and thus contribute to the outermost layer of the central strand: such cells consequently lose their palisade-like form, and in transverse section are liable to be mistaken for tissue confined to the central strand.

The cells forming the outermost layer of the central strand contain chlorophyll, are elongated in the direction of the leaf-axis, and may emit 
lateral lobes that serve to connect them with the surrounding tissue. Thus there is no absolute distinction between the cells of this layer and of the inner palisade-like layer.

The remainder of the central strand is composed of :

(I) parenchyma ;

(2) the single median ventral resin-duct, showing a double epithelium ;

(3) phloem;

(4) xylem, with transfusion tissue.

It was impossible to observe the minute details in the histology on the phloem in the dried herbarium material alone available.

The transfusion-tissue ( $t$. in the illustration) in transverse section extends from the feeble xylem in the form of two wings, which ascend towards the upper face and sometimes curl inwards at the outer edges, which may almost meet in the middle line. The transfusion cells may extend to the outermost layer of the strand. In width of lumen they increase from within outwards ; while in length they vary from long narrow tubes to short cells whose length scarcely exceeds the breadth.

\section{CONCLUSIONS.}

Pherosphaera Fitzgeraldi recalls familiar European shrubs and trees growing in peat-bogs, at alpine altitudes, or in arctic regions, both as regards the construction of its leaves, including the xerophytic epidermis and hypoderma associated with very loose mesophyll, and as regards the narrowness of the annual rings. While the dominance of thick-walled tracheides in the stem is paralleled by similar tendencies in species of Pinus, Larix, and Picea when grown at considerable altitudes in Europe, yet the structure of the leaves is not widely different in design from that displayed by various species of Pinus and Funiperus of more low-lying sites.

The cause of these anatomical features of Pherosphaera Fitzgeraldi, which can grow in a soaking habitat, demands local investigation. Although the Tasmanian species is described as an alpine shrub, such does not appear to be the case with this species. For Dr. Stapf points out that the highest parts of the Blue Mountains, where the plant grows, are clad with Eucalypti, and that the Katoomba plateau (where the specimen described in Hooker's 'Icones Plantarum' was obtained) has a general elevation of 3,000 to $3,500 \mathrm{ft}$. 


\section{$2 \mathrm{BHL}$ Biodiversity Heritage Library}

Groom, Percy. 1916. "A note on the vegetative anatomy of Pherosphaera fitzgeraldi, F. V. M." Annals of botany 30, 311-314.

https://doi.org/10.1093/oxfordjournals.aob.a089596.

View This Item Online: https://www.biodiversitylibrary.org/item/237452

DOI: https://doi.org/10.1093/oxfordjournals.aob.a089596

Permalink: https://www.biodiversitylibrary.org/partpdf/320114

\section{Holding Institution}

Smithsonian Libraries

\section{Sponsored by}

Biodiversity Heritage Library

\section{Copyright \& Reuse}

Copyright Status: Not in copyright. The BHL knows of no copyright restrictions on this item.

This document was created from content at the Biodiversity Heritage Library, the world's largest open access digital library for biodiversity literature and archives. Visit BHL at https://www.biodiversitylibrary.org. 